\title{
Analysis of Effectiveness Measurement of Stretch Blow Machine Using Overall Equipment Effectiveness (OEE) Method
}

\author{
Meike Elsye Beatrix, Hayu Kartika and Sunardiyanta \\ Faculty of Engineering \\ Industrial Engineering Program \\ University of Mercu Buana, Jakarta, 11650, \\ Indonesia
}

\begin{abstract}
This study aims to measure the effectiveness of the Stretch Blow machine at PT. X by calculating the Overall Equipment Effectiveness (OEE) value. Stretch Blow Machine is one of the machines used in the manufacturing process of plastic bottles. These machines often suffer damage so that targets and product quality are often not achieved. The purpose of this study was to determine the most dominant factor of the Six Big Losses on the Stretch Blow Machine. The method used in this research is descriptive quantitative. Based on the results of data processing and analysis, it shows that the average value of Overall Equipment Effectiveness (OEE) for the period January 2017-December 2017 is 43.89\%, while the Overall Equipment Effectiveness (OEE) World Class Value is $>85 \%$. For that, it is necessary to do research using quality control tools, namely Pareto and fishbone diagrams. The results of the data analysis with the Pareto diagram found that the largest Idling Minor and Stoppage Losses is 39.28\%. The causes of Idling Minor and Stoppage Losses based on the results of the fishbone diagram analysis are lack of machine operator skills, unavailable engine spare parts, machine maintenance schedules are not running and the quality of engine spare parts is not suitable. The improvement plan of the factors causing Idling Minor and Stoppage Loses using $5 \mathrm{~W}+1 \mathrm{H}$ have to be implemented so that the Overall Equipment Effectiveness (OEE) value of the Stretch Blow Machine could be increased.
\end{abstract}

Key Words: Stretch Blow, Overall Equipment Effectiveness (OEE), Six Big Losses, Idling losses, Minor Stoppage Losses.

\section{INTRODUCTION}

The Overall Equipment Effectiveness (OEE) is the overall level of the facility's effectiveness obtained by taking into the available material stock, production efficiency, and the quality product [7]. PT. X is a company that produces household products. Some of the products are soap, floor cleaners, and detergents. Besides these products, there are also products like plastic bottles with PET material. And the bottles are produced on the Stretch Blow machine. The company always wants the production output should follow the working plan. The main goal of the business is to serve the customer on time. However, due to various problems that occurred during the production process does not run smoothly. Therefore the achievement of production targets is not following the working plan. The problem faced that the machines often breakdown and the quality product does not meet the specifications. On the other hand, the company is having a contract with the other companies, therefore the company should be ensuring that the quality product should be meet the customer's specifications and on-time delivery.

In this case, the company should have a system for monitoring the performance of the machinery. However, the company has not yet a procedure for measuring the machinery effectiveness is a measure that the states how far the target (quantity, quality, and time) has been achieved. The research is conducted to measure the effectiveness of machines that can provide recommendations of production planning machinery maintenance, especially of the percentages of the production output, downtime machinery, and the speed losses are listed in Table 1. 
International Journal of Advances in Scientific Research and Engineering (ijasre), Vol 6 (8), August -2020

Table 1. Production Data of Stretch Blow Machines

\begin{tabular}{|c|c|c|c|}
\hline $\begin{array}{c}\text { No of } \\
\text { Machines }\end{array}$ & $\begin{array}{c}\text { Production } \\
\text { Output (\%) }\end{array}$ & $\begin{array}{c}\text { Downtime } \\
(\%)\end{array}$ & $\begin{array}{c}\text { Speed Losses } \\
(\%)\end{array}$ \\
\hline SB01 & $63 \%$ & $9 \%$ & $28 \%$ \\
\hline SB02 & $65 \%$ & $13,4 \%$ & $21,6 \%$ \\
\hline SB03 & $72 \%$ & $10 \%$ & $18 \%$ \\
\hline SB04 & $80 \%$ & $13,7 \%$ & $6,3 \%$ \\
\hline
\end{tabular}

In table no. 1, there are four machines that produce PET bottles, namely machines are SB01, SB02, SB03 and SB04. Based on the observations made, an indication of losses in the four machines has been found which is indicated by the presence of Downtime and Speed Losses and which are quite large. The data in Table 1 shows the biggest downtime and speed losses is the SB 01 machine. From the problems that occur, research will be conducted on the SB01 engine to minimize six big losses. One method for optimally increasing engine performance is the Overall Equipment Effectiveness (OEE) method. This measurement method consists of three main interrelated factors namely Availability, Performance, and Quality and also knowing the losses that affect the problem that occurs by calculating Six Big Losses.

\section{METHODOLOGY}

The research on the methods is applied by Overall Equipment Effectiveness (OEE) is a measuring tool to evaluate and improve the right system to guarantee increased productivity of the use of machinery/equipment [14].

The use of OEE as a Performance indicator, takes a certain time base period, such daily, weekly, monthly, or yearly. The theoretical bases used in this study include theories regarding maintenance management systems, Total Productive Maintenance (TPM), Overall Equipment Effectiveness (OEE), and quality improvement techniques (Fishbone Diagram). Overall Equipment Effectiveness (OEE) is the overall level of facility effectiveness that is obtained by taking into account availability, performance efficiency, and rate of quality product [7]. Overall Equipment Effectiveness (OEE) is a measuring tool to evaluate and improve the right system to guarantee increased productivity of machine use.

\section{RESULTS AND DISCUSSION}

Analysis of the results of data processing is divided into 7(seven) parts, namely availability, performance and quality, measurement of Overall Equipment Effectiveness (OEE), measurement of Six Big Losses, Pareto diagram and analysis of causes of problems (cause and effect diagram/fishbone diagram). According to OEE.com the ideal value of Overall Equipment Effectiveness (OEE) is as shown in table 2 below [21].

Table 2. Value of OEE World Class

\begin{tabular}{|c|c|}
\hline OEE and Function & Value \\
\hline Availability & $>90 \%$ \\
\hline Performance Rate & $>95 \%$ \\
\hline Quality Rate & $>99 \%$ \\
\hline OEE & $>85 \%$ \\
\hline
\end{tabular}

\subsection{Data Collection}

In data collection, the author will tabulate the total results of the data obtained from data available time, machine downtime, a performance which consists of cycle time and output product. Then defect product as well during Jan - Dec 2017 as shown in Table 3. 
International Journal of Advances in Scientific Research and Engineering (ijasre), Vol 6 (8), August -2020

Table 3. Data Collections

\begin{tabular}{|c|c|c|c|c|c|c|}
\hline \multirow{2}{*}{ No. } & \multirow{2}{*}{ Month } & $\begin{array}{c}|c| \\
\text { Available } \\
\text { time }\end{array}$ & Downtime & \multicolumn{2}{|c|}{ Performance } & $\begin{array}{c}\text { Defect } \\
\text { Product } \\
\text { (pcs) }\end{array}$ \\
\cline { 3 - 7 } & Hours & Hour & $\begin{array}{c}\text { Cycle time } \\
\text { (Hours) }\end{array}$ & $\begin{array}{c}\text { Output } \\
\text { (pcs) }\end{array}$ & \\
\hline 1 & Jan & 245 & 35 & 0.0007 & 165,000 & 33,500 \\
\hline 2 & Feb & 389 & 55 & 0.0007 & 253,750 & 56,125 \\
\hline 3 & Mar & 69 & 10 & 0.0007 & 44,500 & 8,350 \\
\hline 4 & Apr & 398 & 53 & 0.0007 & 272,200 & 64,660 \\
\hline 5 & May & 64 & 9 & 0.0007 & 42,100 & 7,130 \\
\hline 6 & June & 321 & 45 & 0.0007 & 215,100 & 35,530 \\
\hline 7 & July & 218 & 29 & 0.0007 & 156,650 & 29,095 \\
\hline 8 & Aug & 300 & 40 & 0.0007 & 198,150 & 47,445 \\
\hline 9 & Sept & 60 & 9 & 0.0007 & 39,000 & 7,990 \\
\hline 10 & Oct & 326 & 46 & 0.0007 & 219,200 & 38,460 \\
\hline 11 & Nov & 49 & 7 & 0.0007 & 34300 & 7,290 \\
\hline 12 & Dec & 86 & 11 & 0.0007 & 65,500 & 16,050 \\
\hline
\end{tabular}

\subsection{Overall Equipment Effectiveness (OEE) Data Processing}

To calculate the Overall Equipment Effectiveness (OEE) value, the following formula is used:

$\mathrm{OEE}=$ Availability Ratio $\mathrm{x}$ Performance Ratio $\mathrm{x}$ Quality Ratio $\mathrm{x}$ 100\%

The following is the formulation of Availability ratio, Performance ratio and Quality ratio.

1. The Availability Ratio measures the overall time when the system could not be operating due to broken equipment, production preparation, and parameter settings. In other words, Availability is the measure from the total time in which the equipment is operated after deducting the time for equipment failure and the time for machine preparation and adjustment which also indicated the actual ratio between the Operating time and the Available time. The formulation of Availability as follows:

$A R=\frac{\text { Loading Time }- \text { Downtime }}{\text { Loading Time }} \times 100 \%$

2. The Performance Ratio is measured as the actual operating speed ratio of the equipment at the ideal speed based on design capacity. Nakajima said Performance indicated deviation from the ideal cycle time [14]. The formulation of Performance Ratio as follow:

$$
P E=\frac{\text { Total Produksi }- \text { Cycle Time }}{\text { Operating Time }} \times 100 \%
$$

3. Quality Ratio is the average level products according to a standard compared to products which not follow to the standard. Quality Ratio focused on quality losses in the form of how many products are defective. The formulation of Quality Ratio as follow:

$$
Q R=\frac{\text { Output Produksi }- \text { Jumlah Defect }}{\text { Output Produksi }} \times 100 \%
$$

The Overall Equipment Effectiveness (OEE) calculation analysis is carried out in the plastic department of the PET bottle production department to see the effectiveness of the use of the Stretch Blow machine from January 2017 to December 2017. OEE value is the multiplication of the variables Availability, Performance and Quality. The results of January 2017 to December 2017 are listed in Table 4. 
International Journal of Advances in Scientific Research and Engineering (ijasre), Vol 6 (8), August -2020

Table 4. Overall Equipment Effectiveness (OEE) Results

\begin{tabular}{|c|c|c|c|c|c|}
\hline No. & Month & Availability & Performance & Quality (\%) & OEE $(\%)$ \\
\hline 1 & Jan & 83.3 & 66.6 & 79.6 & 44.16 \\
\hline 2 & Feb & 83.5 & 63.6 & 77.8 & 41.32 \\
\hline 3 & March & 83 & 63.5 & 81.2 & 42.8 \\
\hline 4 & Apr & 84.6 & 65.3 & 76.2 & 42.1 \\
\hline 5 & May & 83.6 & 64 & 83 & 44.41 \\
\hline 6 & June & 83.7 & 65.1 & 83.4 & 45.44 \\
\hline 7 & July & 87.8 & 66 & 81.4 & 47.17 \\
\hline 8 & Aug & 84.6 & 63 & 76 & 40.51 \\
\hline 9 & Sept & 82.3 & 65 & 79.5 & 42.53 \\
\hline 10 & Oct & 83.6 & 65.6 & 82.4 & 45.19 \\
\hline 11 & Nov & 83.3 & 68.6 & 78.7 & 44.97 \\
\hline 12 & Dec & 85.3 & 71.6 & 75.4 & 46.05 \\
\hline \multicolumn{2}{|c|}{ Average } & 84.05 & 65.66 & 79.55 & 43.89 \\
\hline
\end{tabular}

\subsection{Six Big Losses Data Processing}

After obtaining the Overall Equipment Effectiveness (OEE) value during the period Jan 2017 - Dec 2017, then the calculation of Six Big Losses is carried out to find out what factors are the obstacles in the effectiveness of the performance of the Stretch Blow machine. We could see the value of the Six Big Losses in Table 5 and the Pareto diagram in Fig. 1.

Six Big Losses consist of Breakdown Losses, Setup Losses, Idling and Minor Stoppage Losses, Reduced Speed Losses, Reduced Yield Losses, and Defect Losses.

Table 5. Six Big Losses Results

\begin{tabular}{|c|c|c|c|c|c|c|c|}
\hline No. & Month & $\begin{array}{c}\text { Breakdown } \\
\text { Losses (\%) }\end{array}$ & $\begin{array}{c}\text { Setup } \\
\text { Losses } \\
(\%)\end{array}$ & $\begin{array}{c}\text { Idling \& } \\
\text { Minor } \\
\text { Stoppage } \\
\text { Losses (\%) }\end{array}$ & $\begin{array}{c}\text { Reduced } \\
\text { Speed Losses } \\
(\%)\end{array}$ & $\begin{array}{c}\text { Reduced } \\
\text { Yield Losses } \\
(\%)\end{array}$ & $\begin{array}{c}\text { Defect Losses } \\
(\%)\end{array}$ \\
\hline 1 & Jan & 16.67 & 0 & 39.5 & 28.3 & 0 & 11.17 \\
\hline 2 & Feb & 16.46 & 0 & 41.3 & 30.35 & 0 & 11.76 \\
\hline 3 & Mar & 16.94 & 0 & 41.7 & 30.25 & 0 & 9.91 \\
\hline 4 & Apr & 15.36 & 0 & 39.2 & 29.4 & 0 & 13.12 \\
\hline 5 & May & 16.36 & 0 & 40.9 & 30.05 & 0 & 9.07 \\
\hline 6 & June & 16.3 & 0 & 39.9 & 29.14 & 0 & 9.01 \\
\hline 7 & July & 15.34 & 0 & 36.4 & 29.81 & 0 & 10.78 \\
\hline 8 & Aug & 15,38 & 0 & 41.1 & 31.26 & 0 & 12.77 \\
\hline 9 & Sept & 17.64 & 0 & 41 & 28.82 & 0 & 10.97 \\
\hline 10 & Oct & 16.42 & 0 & 39.7 & 28.77 & 0 & 9.62 \\
\hline 11 & Nov & 16.67 & 0 & 37.3 & 26.17 & 0 & 12.15 \\
\hline 12 & Dec & 14.67 & 0 & 33.3 & 24.2 & 0 & 14.98 \\
\hline \multicolumn{2}{|l|}{ Average } & 16.26 & 0.00 & 39.28 & 28.88 & 0.00 & 11.28 \\
\hline
\end{tabular}




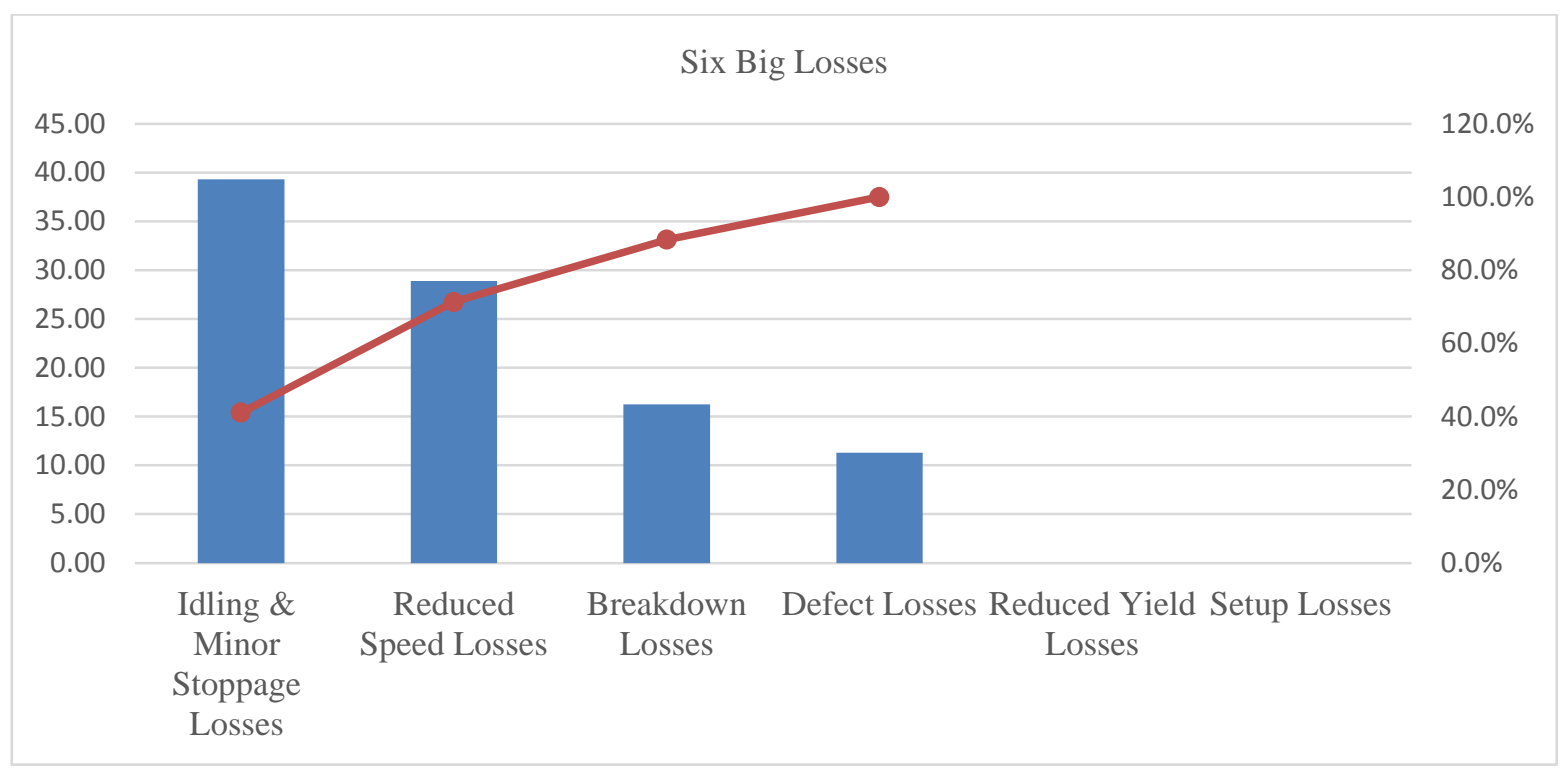

Figure 1. Pareto of Six Big Losses

Based on the result of the Pareto diagram in Fig.1, we could see that the values of Idling and Minor Stoppage Losses is 39.28\%, Reduced Speed Losses is $28.88 \%$, Breakdown Losses is $16.26 \%$, Setup / Adjustment Losses is 0.00\%, defect Losses is $11,28 \%$ and Reduced Yield Losses is $0.00 \%$. From these data, the factors that most influence the effectiveness of the Stretch Blow machine are the Idling Minor factor and stoppage losses with the largest value of other factors is $39.3 \%$. The analysis will be carried out using a fishbone diagram to find out the root cause of the Idling \& Minor Stoppage Losses. Fig. 2 shows a fishbone diagram to find the potential cause of Idling \& Minor Stoppage Losses. .

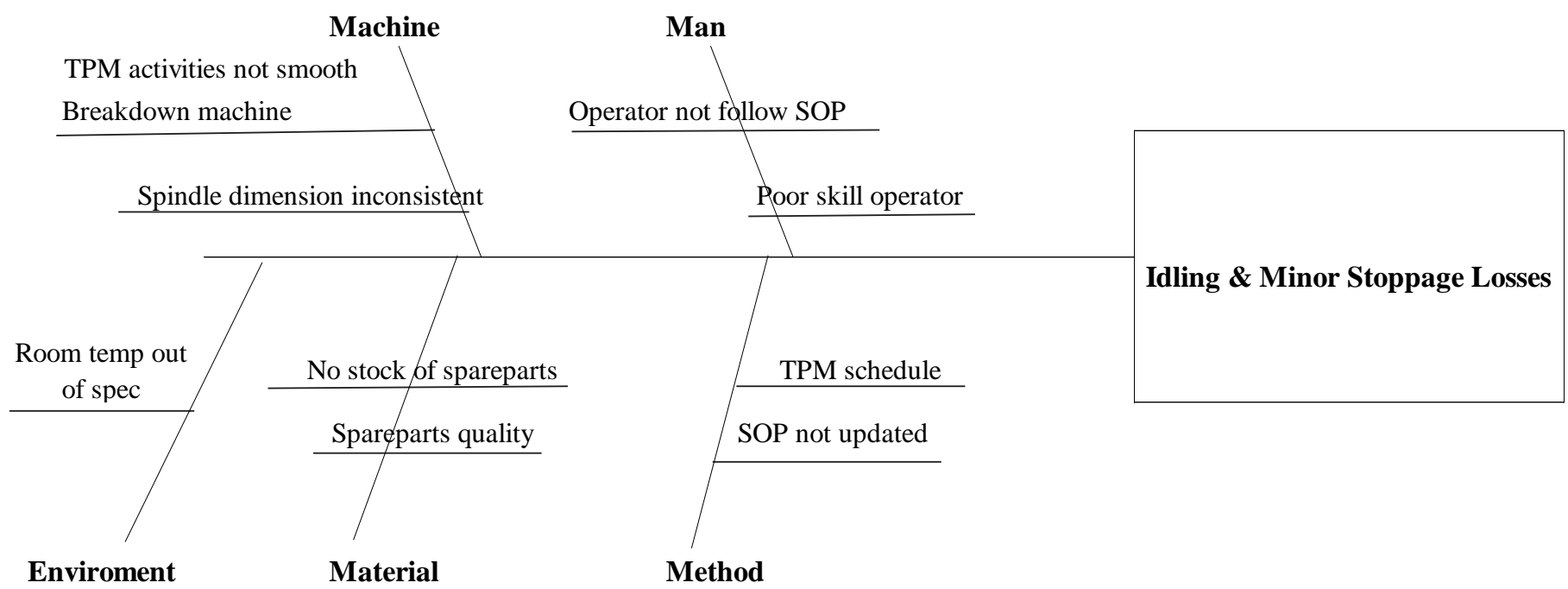

Figure 2. Fishbone Diagram

The Fishbone diagram is one of the seven tools in the quality control system. Meanwhile, it was determined that the Idling \& Minor Stoppage Losses have the highest percentage of the Six Big Losses.

The following is an analysis of $5 \mathrm{~W}+1 \mathrm{H}$ of Idling \& Minor Stoppage Losses as shown in Table 6. 
International Journal of Advances in Scientific Research and Engineering (ijasre), Vol 6 (8), August -2020

Table 6. Improvement Plan of Idling and Minor Stoppage Losses uses 5W + 1H

\begin{tabular}{|c|c|c|c|c|c|c|c|c|}
\hline No. & \multicolumn{2}{|c|}{ Possible Causes } & What & Why & Where & When & Who & How \\
\hline 1. & Machine & $\begin{array}{l}\text { The engine } \\
\text { often } \\
\text { breakdown }\end{array}$ & $\begin{array}{l}\text { Many worn } \\
\text { parts }\end{array}$ & $\begin{array}{l}\text { Spindle that is } \\
\text { not } \\
\text { multifunctional } \\
\text { (when it is } \\
\text { damaged there } \\
\text { is no change) }\end{array}$ & Slip area & $\begin{array}{l}\text { Jan } \\
2018\end{array}$ & $\begin{array}{l}\text { Supervisor } \\
\text { maintenance }\end{array}$ & $\begin{array}{l}\text { Monitoring } \\
\text { Total } \\
\text { Productive } \\
\text { Maintenance } \\
\text { TPM } \\
\text { schedule } \\
\text { activity }\end{array}$ \\
\hline 2. & Method & $\begin{array}{l}\text { Total } \\
\text { Productive } \\
\text { Maintenanc } \\
\text { e (TPM } \\
\text { )scheduled } \\
\text { not running } \\
\text { well }\end{array}$ & $\begin{array}{l}\text { The } \\
\text { lubricating } \\
\text { schedule is } \\
\text { not routine }\end{array}$ & $\begin{array}{l}\text { The machine } \\
\text { lubricating } \\
\text { schedule is } \\
\text { missing }\end{array}$ & $\begin{array}{l}\text { On the } \\
\text { stretch } \\
\text { blow } \\
\text { machine }\end{array}$ & $\begin{array}{l}\text { Jan } \\
2018\end{array}$ & $\begin{array}{l}\text { Supervisor } \\
\text { maintenance }\end{array}$ & $\begin{array}{l}\text { Making the } \\
\text { schedule and } \\
\text { list on } \\
\text { preventive } \\
\text { maintenance } \\
\text { for parts } \\
\text { according to } \\
\text { usage history }\end{array}$ \\
\hline 3. & Man & $\begin{array}{l}\text { Lack of } \\
\text { competenc } \\
\text { y of the } \\
\text { mechanic's } \\
\text { skill }\end{array}$ & $\begin{array}{l}\text { Making } \\
\text { matrix } \\
\text { skills and } \\
\text { equating } \\
\text { skills with } \\
\text { training }\end{array}$ & $\begin{array}{l}\text { For upgrading } \\
\text { mechanic's } \\
\text { skill }\end{array}$ & $\begin{array}{l}\text { Plastic } \\
\text { Departme } \\
\text { nt }\end{array}$ & $\begin{array}{l}\text { Jan } \\
2018\end{array}$ & $\begin{array}{l}\text { Supervisor } \\
\text { maintenance }\end{array}$ & $\begin{array}{l}\text { Making } \\
\text { matrix skills } \\
\text { and equating } \\
\text { skills with } \\
\text { training }\end{array}$ \\
\hline 4 & Material & $\begin{array}{l}\text { Low } \\
\text { quality of } \\
\text { part } \\
\text { material } \\
\text { (spindle } \\
\text { and } \\
\text { stretching } \\
\text { rod } \\
\text { bushing) }\end{array}$ & $\begin{array}{l}\text { Training } \\
\text { related to } \\
\text { inventory } \\
\text { managemen } \\
\text { t system }\end{array}$ & $\begin{array}{l}\text { For upgrading } \\
\text { the skill of } \\
\text { procurement } \\
\text { department }\end{array}$ & $\begin{array}{l}\text { Procureme } \\
\text { nt } \\
\text { Departme } \\
\text { nt }\end{array}$ & $\begin{array}{l}\text { Jan } \\
2018\end{array}$ & $\begin{array}{l}\text { Supervisor } \\
\text { maintenance }\end{array}$ & $\begin{array}{l}\text { Conduct } \\
\text { comparative } \\
\text { studies of } \\
\text { parts from } \\
\text { various } \\
\text { suppliers. }\end{array}$ \\
\hline
\end{tabular}

\section{CONCLUSION}

Based on the processing and data analysis of this study, the conclusions of the researchers as follows. The average Availability Ratio value is $84.05 \%$ which below the Availability value based on OEE World Class should be $90.00 \%$. The average value of the Performance Ratio for the whole period is $65.66 \%$. Judging from the value of the OEE World Class Performance, for the analysis in this study that is $95 \%$, it can be concluded that the machine analyzed is still below the OEE World-Class value for measuring the Overall Equipment Effectiveness (OEE) value. The average value of the Quality Ratio for the whole period was $79.55 \%$. Judging from the Quality OEE World-Class value for the analysis in this study that is $99 \%$, it can be concluded that the machine analyzed is below the Quality OEE World-Class value. The most influential factor on the effectiveness of the Stretch Blow machine is the Idling Minor factor and Stoppage Losses with the largest value of the other factors that is $39.28 \%$. Idling Minor and stoppage losses are a large Losses value that is comparable with a small Performance value on OEE.

\section{REFERENCES}

[1] Alvira, Dianra, dkk. 2015. Usulan Peningkatan Overall Equipment Effectiveness Pada Mesin Tapping Manual dengan Meminimumkan Six Big Losses. Bandung. Jurnal Online Institut Teknologi Nasional. Vol.03, No.03. ISSN: 2338-5081.

[2] Amin Syukron dan Muhammad Kholil, Pengantar Teknik Industri.Yogyakarta: Graha Ilmu, 2014.

[3 Arunagiri, P., A. Gnanavelbabu. 2014. Identification of High Impact Lean Production Tools in Automobile Industries Using Weighted Average Method. India: Organizing Comitee of GCMM. Elsevier Ltd. Procedia Engineering 97: 2072-2080. 
[4] Asgara, Badik Yuda, dkk. 2014. Analisis Efektifitas Mesin Overhead Crane Dengan Metode Overall Equipment Effectiveness Di PT BTU, Divisi Boarding Bridge. Serpong. Jurnal Universitas Bina Nusantara.Vol. 15, No. 1, 62-70.

[5] Asmara, Teddy. 2013. Analisis Perhitungan Overall Equipment Effectiveness Proses Produksi Tissue Softpack Mesin Interfolder Sofia01 di PT Graha Cemerlang Paper Utama. Jurnal STT Wastukancana. Vol.04, No.02.

[6] Azizi, Amir. 2015. Evaluation Improvement of Production Productivity Performance Using Statistical Process Control, Overall Equipment Efficiency, and Autonomous Maintenance. Malaysia: Scientific Commitee of MIMEC. Elsevier Ltd. Procedia Engineering 02: 186-190.

[7] Davis, R K. 1995. Productivity Improvement Through TPM, London: Prentice Hall.

[8] Hansen, R. C. (2001), Overall Equipment Effectiveness: A Powerful Production / Maintenance Tool for In Creased Profit, 1 Edition. New York: Industrial Press Inc.

[9] Hapsari, Nindita, dkk. 2012. Pengukuran Efektivitas Mesin Dengan Menggunakan Metode Overall Equipment Effectiveness Di PT Setiaji Mandiri. Yogyakarta: Universitas Ahmad Dahlan. ISSN: 1963-6590.

[10] Hegde, Harsha G., N.S. Mahesh, K. Doss. 2009. Overall Equipment Effectiveness Improvement by TPM and 5S Techiniques in a CNC Machine Shop. Vol 8 (2):25-32.

[11] Hesti, Dinda, dkk. 2013. Analisis Overall Equipment Effectiveness Dalam Meminimalisasi Six Big Losses Pada Mesin Produksi Dual Filters DD07. Malang: Universitas Brawijaya. Vol.01, No.02, hal.379-391.

[12] Jeong, Ki-Young., Philips, Don T. 2001. Operational Efficiency and Effectiveness Measurement. International Journal of Operation \& Production Management, Vol 21 No. 11, pp 1404-1416.

[13] Kumar, Pavan, dkk. Implementation of 5S and Kobetsu Kaizen (TPM Pillar) in Manufacturing Organization. India: International Research Journal of Engineering and Technology (IRJET). E-ISSN: 2395 -0056, P-ISSN: $2395-0072$.

[14] Nakajima, S. 1988. Introduction to Total Productive Maintenance. Portland:Productivity Press, Inc.

[15] P. Ahire, Chdanrajit dan Andan S. Relkar. 2012. Correlating Failure Mode Effect Analysis (FMEA) and Overall Equipment Effectiveness (OEE). India: Noorul Islam Centre for Higher Education ICMOC. Elsevier Ltd. Procedia Engineering 38:38423486 .

[16] Rahmad, Pratikto dan Wahyudi, S. 2012. Penerapan Overall Equipment Effectiveness (OEE) dalam Implementasi Total Productive Maintenance (TPM) (Studi Kasus di Pabrik Gula PT. 'Y'). Jurnal Rekayasa Mesin, 3(3), hal. $431-437$.

[17] Shah, Mihir. K, dkk. 2017. Application of Lean Tools for Improving Overall Equipment Effectiveness (OEE) and Productivity in Panel Shop of heavy Fabrication Industry. India: Proceedings of 2nd International Conference on Emerging Trends in Mechanical Engineering IE11, ISBN: 978-93-84659-77-6.

[18] Vorne Industries. 2008. The Fast Guide to OEE. Itasca, IL USA.

[19] Stephens, M. P. 2004. Productivity and Reliability-based Maintenance Management. New Jersey: Pearson Edication Inc.

[20] Sugiyono. 2011. Metode Penelitian Kuantitatif kualitatif dan R\&D. Bandung: Alfabeta.

[21] Vorne Industries. 2008. The Fast Guide to OEE. IL USA: Itasca, https://www.oee.com/oee-six-big-losses.html 